IJBPAS, May, 2021, 10(5): 1701-1719

ISSN: $2277-4998$

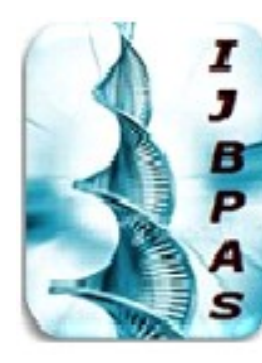

International Journal of Biology, Pharmacy and Allied Sciences (IJBPAS)

'A Bridge Betueen Caboratory and Q Qundo'

WWw.iibpas,com

\title{
DEVELOPMENT OF STABILITY INDICATING RP-HPLC METHOD FOR SIMULTANEOUS ESTIMATION OF IVABRADINE AND METOPROLOL IN PHARMACEUTICAL DOSAGE FORM AND IN BLOOD PLASMA
}

\author{
KUMAR $D^{1^{*}}$, PANDA SK ${ }^{2}$, SAHOO SK ${ }^{2}$ AND MANDAL SK ${ }^{3}$
}

1: Research Scholar, BPUT, Rourkela, Odisha, India

2: Royal College of Pharmacy and Health Sciences, Berhampur, Gnajam, Odisha, India

3: Dr. B. C. Roy College of Pharmacy and A.H.S., Durgapur-713206, West Bengal, India

*Corresponding Author: E Mail: dhirajkumar5707@gmail.com; Phone: 9985816825

Received 20 ${ }^{\text {th }}$ June 2020; Revised 22 ${ }^{\text {nd }}$ July 2020; Accepted 27 ${ }^{\text {th }}$ Aug. 2020; Available online $1^{\text {st }}$ May 2021

\section{https://doi.org/10.31032/IJBPAS/2021/10.5.5489}

\section{ABSTRACT}

A simple reverse phase HPLC method was developed for the simultaneous estimation of Ivabradine and Metoprolo in bulk and tablet form. Chromatography was performed by isocratic reverse phase separation on a stainless steel column $4.6 \times 150 \mathrm{~mm}$, symmetry column packed with octa decyl silane bonded to porous silica $(\mathrm{C} 18)$ with particle size 5 micron with mobile phase containing Methanol and phosphate buffer in the ratio of 50:50. The flow rate was $0.8 \mathrm{ml} /$ min and effluent was monitored at $260 \mathrm{~nm}$. The retention times were $2.24 \mathrm{~min}$ and $2.66 \mathrm{~min}$ Metoprolol and Ivabradine respectively. The standard curve was linear over a working range of $25-150 \mu \mathrm{g} / \mathrm{ml}$ for Metoprolol and 5-30 $\mu \mathrm{g} / \mathrm{ml}$ for Ivabradine and gave an average correlation coefficient of 0.999 , and 0.999 for Metoprolol and Ivabradine respectively. The limit of quantitation (LOQ) of this method was $0.56 \mu \mathrm{g} / \mathrm{ml}$ and $3.8 \mu \mathrm{g} / \mathrm{ml}$ for Metoprolol and Ivabradine respectively. The absolute recovery was $99.96 \%$ for Metoprolol and 99.86 for Ivabradin. Degradation products produced as a result of stress studies did not interfere with the detection of Metoprolol and Ivabradine, the assay can thus be considered stability-indicating.

Keywords: Metoprolol, Ivabradine, RP-HPLC, Phosphate Buffer, Methanol, Validation 


\section{INTRODUCTION}

Metoprolol is a beta-blocker that affects the heart and circulation (blood flow through arteries and veins). Metoprolol is used to treat angina (chest pain) and hypertension (high blood pressure). Metoprolol is also used to lower your risk of death or needing to be hospitalized for heart failure $[3,4]$.

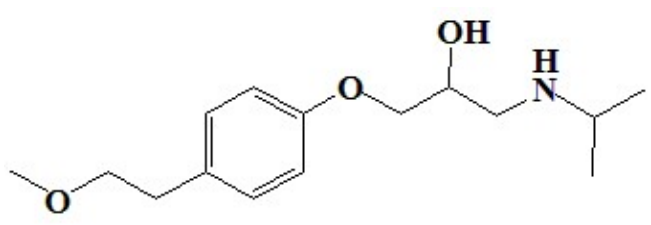

Figure 1: Metoprolol

Metoprolol is a beta-1-adrenergic receptor inhibitor specific to cardiac cells with negligible effect on beta- 2 receptors. This inhibition decreases cardiac output by producing negative chronotropic and inotropic effects without presenting activity towards membrane stabilization nor intrinsic sympathomimetics [1].

Ivabradine is a novel heart rate lowering medicine for the symptomatic management of stable angina pectoralis and symptomatic chronic heart failure. Ivabradine was approved by the FDA in for the treatment of chronic heart failure in patients with an ejection fraction of $\leq 35 \%$, in sinus rhythm with resting heart rate $\geq 70$ beats per minute, who are not on beta-blockers due to contraindications or already receiving maximum beta-blocker dose $[\mathbf{1}, \mathbf{2}]$.

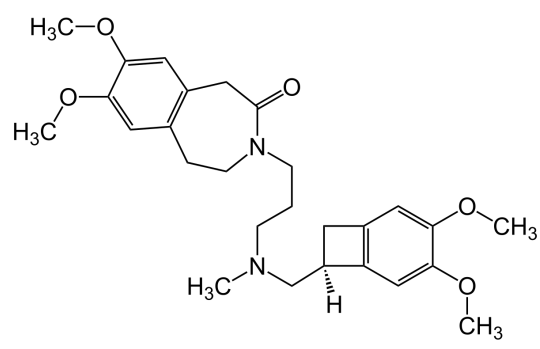

Figure 2: Ivabradine

Ivabradine lowers heart rate by selectively inhibiting If channels ("funny channels") in the heart in a concentration-dependent manner without affecting any other cardiac ionic channels (including calcium or potassium). Ivabradine binds by entering and attaching to a site on the channel pore from the intracellular side and disrupts If ion current flow, which prolongs diastolic depolarization, lowering heart rate. The currents are located in the sinoatrial node and are the home of all cardiac pacemaker activity. Ivabradine therefore lowers the pacemaker firing rate, consequently lowering heart rate and reducing myocardial oxygen demand. This allows for an improved oxygen supply and therefore mitigation of ischemia, allowing for a higher exercise capacity and reduction in angina episodes.

\section{MATERIALS AND METHODS \\ Drugs}

Pure pharmaceutical sample of Ivabradine (IVR) and Metoprolol (MET) was obtained 
from Yucca Pharma. Commercial tablet of Ivabradine (IVR) (5mg), Metoprolol (25mg) Ivamet XL $5 \mathrm{mg} / 25 \mathrm{mg}$ were procured from the local drug market [6-9].

\section{Chemicals}

Potassium dihydrogen phosphate (AR Grade), 85\% Orthophosphoric acid (AR Grade), Methanol (HPLC Grade), Orthophosphoric acid (AR Grade), TriethylAmine (AR Grade), Sodium Hydroxide (AR Grade) were purchased from Sd fine-Chem limited [3].

\section{Instrument}

Liquid chromatographic system from Waters alliance 2695 with Waters UV detector equipped with Empower software was used.

Preparation of mobile phase:

Preparation of Phosphate buffer:

Accurately weighed 6.8 grams of $\mathrm{KH}_{2} \mathrm{PO}_{4}$ was taken in a $1000 \mathrm{ml}$ volumetric flask, dissolved and diluted to $1000 \mathrm{ml}$ with HPLC water and the volume was adjusted to $\mathrm{pH} 3.0$ with Orthophosphoric acid.

\section{Mobile phase:}

Accurately measured $500 \mathrm{ml}(50 \%)$ of above buffer and $500 \mathrm{ml}$ of Methanol HPLC (50\%) were mixed and degassed in an ultrasonic water bath for 10 minutes and then filtered through $0.45 \mu$ filter under vacuum filtration [5].

Diluent Preparation:
The Mobile phase was used as the diluents.

Preparation of Standard stock solutions: Accurately weighed $5 \mathrm{mg}$ of Ivabradine, 25 $\mathrm{mg}$ of Metoprolol and transferred to individual $50 \mathrm{ml}$ volumetric flasks separately. $3 / 4$ th of diluents was added to both of these flasks and sonicated for 10 minutes. Flasks were made up with diluents and labeled as Standard stock solution 1and 2. $(50 \mu \mathrm{g} / \mathrm{ml}$ of Ivabradine and $250 \mu \mathrm{g} / \mathrm{ml}$ of Metoprolol)

Preparation of Standard working solutions (100\% solution): $1 \mathrm{ml}$ from each stock solution was pipetted out and taken into a $10 \mathrm{ml}$ volumetric flask and made up with diluent. $(5 \mu \mathrm{g} / \mathrm{ml}$ Ivabradine of and $25 \mu \mathrm{g} / \mathrm{ml}$ of Metoprolol)

Preparation of Sample stock solutions: 10 tablets were weighed and the average weight of each tablet was calculated, then the weight equivalent to 1 tablet was transferred into a $100 \mathrm{ml}$ volumetric flask, $25 \mathrm{ml}$ of diluents was added and sonicated for $25 \mathrm{~min}$, further the volume was made up with diluent and filtered by HPLC filters $(50 \mu \mathrm{g} / \mathrm{ml}$ of Ivabradine and $250 \mu \mathrm{g} / \mathrm{ml}$ of Metoprolol).

\section{Preparation of Sample working solutions} (100\% solution): $1 \mathrm{ml}$ of filtered sample stock solution was transferred to $10 \mathrm{ml}$ volumetric flask and made up with diluent. $(5 \mu \mathrm{g} / \mathrm{ml}$ of Ivabradine and $25 \mu \mathrm{g} / \mathrm{ml}$ of Metoprolol). 


\section{Validation Parameter}

\section{Linearity:}

Preparation of Standard stock solutions:

Accurately weighed $2.5 \mathrm{mg}$ of Ivabradine, $12.5 \mathrm{mg}$ of Metoprolol and transferred to individual $50 \mathrm{ml}$ volumetric flasks separately. $3 / 4$ th of diluents was added to both of these flasks and sonicated for 10 minutes. Flasks were made up with diluents and labeled as Standard stock solution land 2. $(50 \mu \mathrm{g} / \mathrm{ml}$ of Ivabradine and $250 \mu \mathrm{g} / \mathrm{ml}$ of Metoprolol)

25\% Standard solution: $1 \mathrm{ml}$ each from two standard stock solutions was pipetted out and made up to $10 \mathrm{ml}$. $(5 \mu \mathrm{g} / \mathrm{ml}$ of Ivabradine and $25 \mu \mathrm{g} / \mathrm{ml}$ of Metoprolol).

50\% Standard solution: $2 \mathrm{ml}$ each from two standard stock solutions was pipetted out and made up to $10 \mathrm{ml}$. (10 $\mu \mathrm{g} / \mathrm{ml}$ of Ivabradine and $50 \mu \mathrm{g} / \mathrm{ml}$ of Metoprolol).

$\mathbf{7 5 \%}$ Standard solution: $3 \mathrm{ml}$ each from two standard stock solutions was pipetted out and made up to $10 \mathrm{ml}$. (15 $\mu \mathrm{g} / \mathrm{ml}$ of Ivabradine and $75 \mu \mathrm{g} / \mathrm{ml}$ of Metoprolol).

$100 \%$ Standard solution: $4 \mathrm{ml}$ each from two standard stock solutions was pipetted out and made up to $10 \mathrm{ml}$. $(20 \mu \mathrm{g} / \mathrm{ml}$ of Ivabradine and $100 \mu \mathrm{g} / \mathrm{ml}$ of Metoprolol).

125\% Standard solution: $5 \mathrm{ml}$ each from two standard stock solutions was pipetted out and made up to $10 \mathrm{ml}$. $(25 \mu \mathrm{g} / \mathrm{ml}$ of Ivabradine and $125 \mu \mathrm{g} / \mathrm{ml}$ of Metoprolol).

150\% Standard solution: $6 \mathrm{ml}$ each from two standard stock solutions was pipettede out and made up to $10 \mathrm{ml}$. ( $30 \mu \mathrm{g} / \mathrm{ml}$ of Ivabradine and $150 \mu \mathrm{g} / \mathrm{ml}$ of Metoprolol).

\section{Accuracy:}

Preparation of Standard stock solutions: Accurately weighed $2.5 \mathrm{mg}$ of Ivabradine, $12.5 \mathrm{mg}$ of Metoprolol and transferred to individual $50 \mathrm{ml}$ volumetric flasks separately. 3/4 th of diluents was added to both of these flasks and sonicated for 10 minutes. Flasks were made up with diluents and labeled as Standard stock solution 1and 2. $(50 \mu \mathrm{g} / \mathrm{ml}$ of Ivabradine and $250 \mu \mathrm{g} / \mathrm{ml}$ of Metoprolol)

Preparation of 50\% Spiked Solution: $1 \mathrm{ml}$ of sample stock solution was taken into a $10 \mathrm{ml}$ volumetric flask, to that $0.5 \mathrm{ml}$ from each standard stock solution was pipetted out, and made up to the mark with diluent.

\section{Preparation of $100 \%$ Spiked Solution:}

$1.0 \mathrm{ml}$ of sample stock solution was taken into a $10 \mathrm{ml}$ volumetric flask, to that $1.0 \mathrm{ml}$ from each standard stock solution was pipetted out, and made up to the mark with diluent.

\section{Preparation of $150 \%$ Spiked Solution:} $1.5 \mathrm{ml}$ of sample stock solution was taken into a $10 \mathrm{ml}$ volumetric flask, to that $1.0 \mathrm{ml}$ 
from each standard stock solution was pipetted out, and made up to the mark with diluent.

Robustness: Small deliberate changes in method like Flow rate, mobile phase ratio, and temperature are made but there were no recognized change in the result and are within range as per ICH Guide lines.

Robustness conditions like Flow minus $(0.9 \mathrm{ml} / \mathrm{min})$, Flow plus $(1.1 \mathrm{ml} / \mathrm{min})$, mobile phase minus, mobile phase plus, temperature minus $\left(25^{\circ} \mathrm{C}\right)$ and temperature plus $\left(35^{\circ} \mathrm{C}\right)$ was maintained and samples were injected in duplicate manner. System suitability parameters were not much affected and all the parameters were passed. \%RSD was within the limit.

LOD sample Preparation: $0.25 \mathrm{ml}$ each from two standard stock solutions was pipetted out and transferred to two separate $10 \mathrm{ml}$ volumetric flasks and made up with diluents. From the above solutions $0.1 \mathrm{ml}$ each of Ivabradine, Metoprolol, solutions respectively were transferred to $10 \mathrm{ml}$ volumetric flasks and made up with the same diluents

LOQ sample Preparation: $0.25 \mathrm{ml}$ each from two standard stock solutions was pipetted out and transferred to two separate $10 \mathrm{ml}$ volumetric flask and made up with diluent. From the above solutions $0.3 \mathrm{ml}$ each of Ivabradine, Metoprolol, and solutions respectively were transferred to $10 \mathrm{ml}$ volumetric flasks and made up with the same diluent.

\section{Apparatus and Chromatographic conditions:}

Quantitative HPLC was performed on Waters HPLC system with UV detector. empower software is used along with a stainless steel column 4.6 x $150 \mathrm{~mm}$, packed with Octa decyl silane bonded to porous silica (C18) with particle size 5 micron. To develop a suitable and robust HPLC method for the determination of IVR and MET, different mobile phases containing buffer and Methanol were used in different compositions like (30:70, 40:60, $50: 50,70: 30,80: 20)$ at different flow rates $(0.5,0.75,1.0,1.2,1.5, \mathrm{ml} / \mathrm{min})$. The mobile phase containing buffer and methanol with a flow rate of $0.8 \mathrm{ml} / \mathrm{min}$ gave peaks of good resolution and were eluted at retention times around $2.23 \mathrm{~min}, 2.65 \mathrm{~min}$ with symmetric peak shape. The detection is performed at the wavelength $260 \mathrm{~nm}$ [6-9].

\section{Running the standard solution of Metoprolol and Ivabradine}

$1 \mathrm{ml}$ each from two standard stock solutions was pipetted out and made up to $10 \mathrm{ml}$. $(5 \mu \mathrm{g} / \mathrm{ml}$ of Ivabradine and $25 \mu \mathrm{g} / \mathrm{ml}$ of Metoprolol). The solution was filtered through the $0.45 \mu \mathrm{m}$ membrane filter and degassed under ultrasonic bath prior to use. The solution was injected into the HPLC system. The chromatogram obtained is shown in Figure 3. 


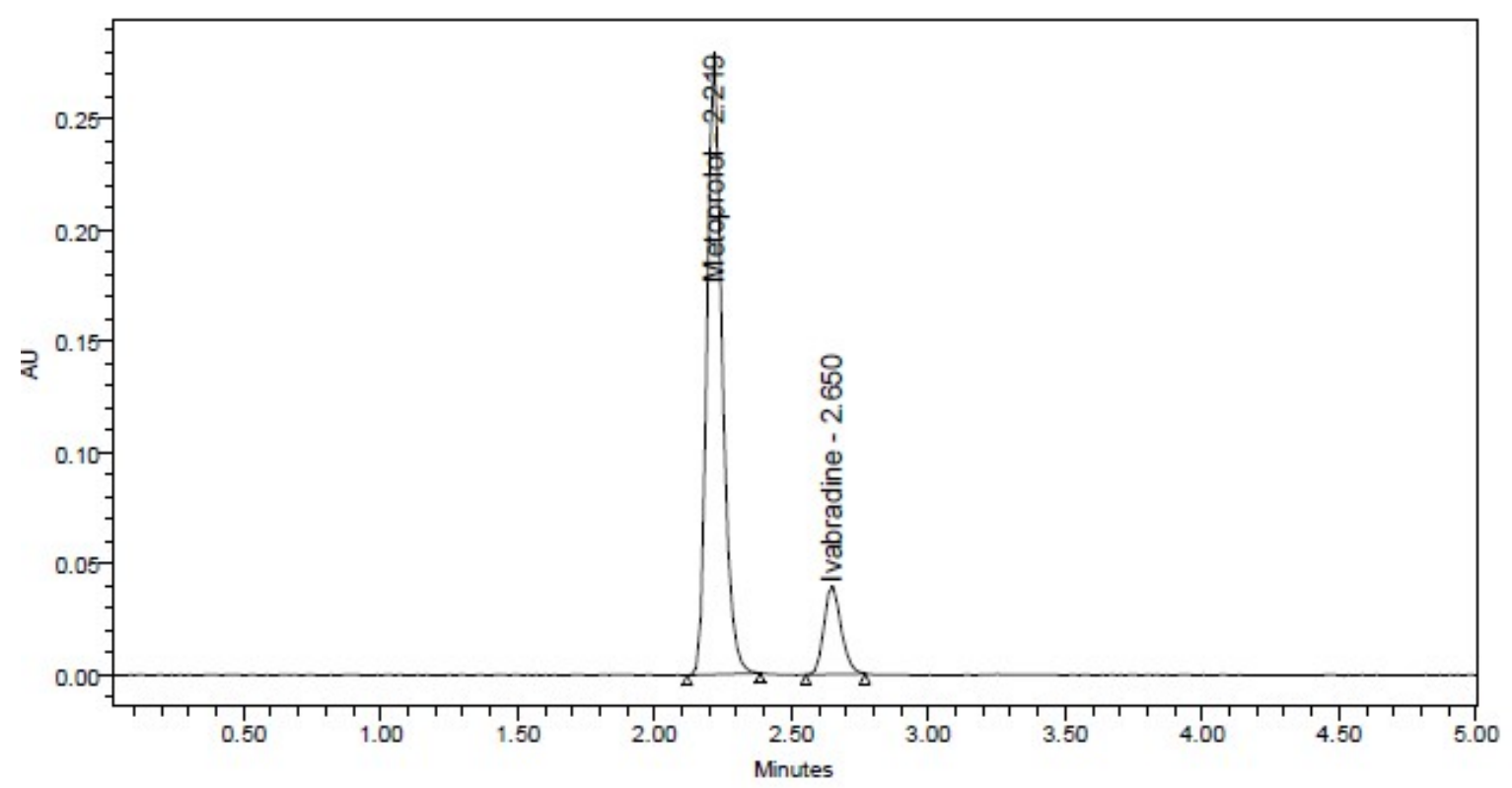

Figure 3: Chromatogram of Metoprolol (Rt-2.21 min) and Ivabradine (Rt-2.66min)

\begin{tabular}{|c|c|c|c|c|c|}
\hline S. No. & Name & $\begin{array}{c}\text { Retention } \\
\text { time(min) }\end{array}$ & $\begin{array}{c}\text { Area }(\mu \mathrm{V} \\
\text { sec) }\end{array}$ & $\begin{array}{c}\text { USP } \\
\text { tailing }\end{array}$ & $\begin{array}{c}\text { USP plate } \\
\text { count }\end{array}$ \\
\hline 1 & Metoprolol & 2.21 & 1089296 & 1.26 & 7567 \\
\hline 2 & Ivabradine & 2.66 & 170797 & 1.16 & 9151 \\
\hline
\end{tabular}

\section{RESULTS AND DISCUSSION}

Method development and optimization: The main target of the chromatographic method is to get the separation of closely eluting drugs Metoprolol and Ivabradine, The drugs were co-eluted by using different stationary phases like C18, C8 with varying lengths and different mobile phases containing buffers like phosphate, sulphate and acetate with different $\mathrm{pH}$ (2-7) and using organic modifiers like acetonitrile, methanol and ethanol in the mobile phase. $\mathrm{pH}$ of the buffer has played a significant role in achieving the separation between drugs.
The chromatographic separation was achieved on a stainless steel column (4.6 x $250 \mathrm{~mm}$ ) column packed with Octa decyl silane bonded to porous silica $(\mathrm{C} 18)$ with particle size 5 micron, by using solutions phosphate buffer and methanol in the ratio of (50:50), pH adjusted to 4 using ortho phosphoric acid. The flow rate of the mobile phase was maintained at $0.8 \mathrm{ml} / \mathrm{min}$. At $25^{\circ}$ $\mathrm{C}$ of column temperature, the peak shape of MET and IVR was found symmetrical with mobile phase 50:50 ratio. In the optimized conditions MET and IVR were well separated with a good resolution and the 
typical retention times of MET and IVR were about $2.2 \mathrm{~min}$ and $2.6 \mathrm{~min}$, respectively. The system suitability results are given in Table 1 and the developed LC method was validated [10-14].

\section{Results of method validation}

Linearity: Linear calibration plot for assay method was obtained over the calibration ranges tested, i.e. $1-37.5 \mu \mathrm{g} / \mathrm{ml}$ for Metoprolol and $1 \mu \mathrm{g} / \mathrm{ml}$ to $7.5 \mu \mathrm{g} / \mathrm{ml}$ for Ivabradine and the correlation coefficient obtained was greater than 0.999 . The results show that an excellent correlation existed between the peak area and concentration of the analyte which is given in Table 2 and 3, Figure 4, 5.

\section{Precision/ruggedness:}

To evaluate the intermediate precision (also known as Ruggedness) of the method, Precision was performed on different day by using different make column of same dimensions (Table 4, 5, 6).

\section{System Precision (Table 6)}

Recovery and accuracy: The percentage recovery of MET and IVR in bulk drugs samples was ranged from 99.96 - 99.86\% which indicates that the method was accurate which is given in Table 7 .

\section{Accuracy results:}

The accuracy of the method was determined by preparing solutions of different concentrations of MET and IVR that is $50 \%$, $100 \%$ and $150 \%$ in which the amount of marketed formulation (MET and IVR $20 \mu \mathrm{g}$ and $100 \mu \mathrm{g}$ respectively) was kept constant and the amount of pure drug was varied that is $10 \mu \mathrm{g}, 20 \mu \mathrm{g}$ and $30 \mu \mathrm{g}$ for IVR and $50 \mu \mathrm{g}$, $100 \mu \mathrm{g}$ and $150 \mu \mathrm{g}$ for MET i.e. 50\%, 100\% and $150 \%$ respectively. The solutions were prepared in triplicates and the accuracy. similarly was indicated by $\%$ recovery in Table 7 and 8.

\section{LOD and LOQ: Detection limit and} Quantitation limit of described method were observed as given in (Table 9).

\section{ROBUSTNESS:}

Robustness is a measure of capacity of a method to remain unaffected by small, but deliberate variations in the method conditions, and is indications of the reliability of the method. A method is robust, if it is unaffected by small changes in operating conditions. To determine the robustness of this method, the experimental conditions were deliberately altered at three different levels and retention time and chromatographic response were evaluated. One factor at a time was changed to study the effect. Variation of wavelength (235 and 239 $\mathrm{nm}$ ) and mobile phase flow rate by 0.1 $\mathrm{ml} / \mathrm{min} \quad(0.9$ and $1.0 \mathrm{ml} / \mathrm{min})$ had no significant effect on the retention time and 
chromatographic response of the $20 \mu \mathrm{g} / \mathrm{ml}$ and $100 \mu \mathrm{g} / \mathrm{ml}$ for ivabradine and Metoprolol solution respectively, indicating that the method was robust.

Influence of small changes in chromatographic conditions such as change in flow rate $( \pm 0.1 \mathrm{ml} / \mathrm{min})$, Temperature $\left( \pm 2^{0} \mathrm{C}\right)$, Wavelength of detection $( \pm 2 \mathrm{~nm})$ \& methanol content in mobile phase $( \pm 2 \%)$ studied to determine the robustness of the method are also in favour of (Table 10, 11; $\%$ RSD $<2 \%$ ) the developed RP-HPLC method for the analysis of Amlodipine.

\section{STABILITY STUDY:}

\section{Acid Hydrolysis:}

Accurately weighed $25 \mathrm{mg}$ of Ivabradine, $25 \mathrm{mg}$ of Metoprolol and transferred to individual $25 \mathrm{ml}$ volumetric flasks separately. $3 / 4$ th of diluents was added to both of these flasks and sonicated for 10 minutes. Flasks were made up with diluents and labeled as standard solution 1 and 2. (1 $\mathrm{mg} / \mathrm{ml}$ of Ivabradine and Metoprolol) (Figure 6).

The mixture of Ivabradine and Metoprolol (1 $\mathrm{mg} / \mathrm{ml}$ ) was treated with $2 \mathrm{ml} 0.1 \mathrm{~N} \mathrm{HCl}$ and heated at $60^{\circ} \mathrm{C}$ for $6 \mathrm{hr}$. The mixture was cooled at room temperature. The resultant solution was neutralized and diluted to obtain 20ppm and 100ppm of Ivabradine and Metoprolol solution respectively. $10 \mu 1$ solutions were injected into the system and the chromatograms were recorded to assess the stability of sample [15-17].

\section{Basic Hydrolysis}

The mixture of Ivabradine and Metoprolol (1 $\mathrm{mg} / \mathrm{ml}$ ) was treated with $2 \mathrm{ml} 0.1 \mathrm{~N}$ sodium and heated at $60^{\circ} \mathrm{C}$ for $6 \mathrm{hr}$. The mixture was cooled at room temperature. The resultant solution was neutralized and diluted to obtain $20 \mathrm{ppm}$ and $100 \mathrm{ppm}$ of Ivabradine and Metoprolol solution respectively. From the resultanty solution 10 $\mu 1$ solutions were injected into the system and the chromatograms were recorded to assess the stability of sample (Figure 7).

\section{Dry Heat Degradation}

The mixture of Ivabradine and Metoprolol $(1 \mathrm{mg} / \mathrm{ml})$ was placed in oven at $80^{\circ} \mathrm{C}$ for 24 hour to study dry heat degradation. For HPLC study, the resultant solution was diluted to obtain $20 \mathrm{ppm} \&$ $100 \mathrm{ppm}$ of Ivabradine, \& Metoprolol solution respectively. From the resultant solution $10 \mu 1$ were injected into the system, the chromatograms obtained were recorded to assess the stability of the sample (Figure 8).

\section{Photolytic Degradation:}

To study the photochemical stability the mixture of Ivabradine and Metoprolol (1 
$\mathrm{mg} / \mathrm{ml}$ ) drug was exposed to UV Light (254 $\mathrm{nm}$ and $366 \mathrm{~nm}$ ) by keeping the drug in UV Chamber for 24 hours. For HPLC study, the resultant solution was diluted to obtain (20ppm \& 400ppm) solutions and $10 \mu 1$ were injected into the system. The chromatograms were recorded to assess the stability of sample (Figure 9).

\section{Oxidation With (3\%) $\mathrm{H}_{2} \mathrm{O}_{2}$ :}

The mixture of Ivabradine and Metoprolol (1 $\mathrm{mg} / \mathrm{ml}$ ) was added with $2 \mathrm{ml}$ of $3 \%$ hydrogen peroxide $\left(\mathrm{H}_{2} \mathrm{O}_{2}\right)$ and the mixture was refluxed at $60^{\circ} \mathrm{C}$ for 6 hours. For HPLC study, the resultant solution was diluted to obtain (20ppm, \& 100ppm) solution and $10 \mu 1$ were injected into the system and the chromatograms were recorded to assess the stability of sample (Figure 10).

\section{Neutral Degradation Studies:}

Stress testing under neutral conditions was studied by refluxing the drug in water for $6 \mathrm{hrs}$ at a temperature of $60^{\circ} \mathrm{c}$. For HPLC study, the resultant solution was diluted to (20ppm \& 100ppm) solution and $10 \mu 1$ were injected into the system and the chromatograms were recorded to assess the stability of the sample (Figure 11).

\section{Results of forced degradation studies:}

The results of the stress studies indicated the specificity of the method that has been developed. Ivabradine and Metoprolol were stable in photolytic, thermal and basic stress conditions. The result of forced degradation studies are given in the following Table 12.

\section{Results of Plasma studies:}

The mixture of drug sample containing Ivabradine $0.2 \mathrm{mg}$ and Metoprolol $1 \mathrm{mg}$ was introduced orally in the 3 rats. Animal was allowed to access to food $4 \mathrm{~h}$ after dose administration. $1 \mathrm{ml}$ of blood sample was withdrawn from lateral tail vein with help of heparinise catheter and syringe at time intervals of 0 (pre-dose), 4, 6, 8, 12, and $24 \mathrm{hr}$ post administration. The plasma was separated by centrifugation at $4000 \mathrm{rpm}$ for $15 \mathrm{~min}$ and was stored at $-20^{\circ} \mathrm{C}$ till analysis.

Plasma samples $(1 \mathrm{~mL})$ in $13 \times 100$ $\mathrm{mm}$ glass test tubes. was treated with of $10 \mathrm{M}$ sodium hydroxide solution. The sample obtained from Liquid- liquid extraction is injected into the chromatographic system for quantitation (Figure 12-15). 
Table 1: System suitability parameters

\begin{tabular}{|c|c|}
\hline Instrument used & : Waters HPLC with auto sampler and UV detector \\
\hline Temperature & Ambient \\
\hline Column & Inertsil C18 (4.6 x 150mm, $5 \mu \mathrm{m})$ \\
\hline Buffer & $\begin{array}{c}\text { Accurately weighed } 6.8 \text { grams of KH2PO4 dissolved } 1000 \mathrm{ml} \text {. volume was adjusted to } \\
\text { pH 4.0 with Orthophosphoric acid }\end{array}$ \\
\hline pH & 4 \\
\hline Mobile phase & $50 \%$ buffer and $50 \%$ Methanol \\
\hline Flow rate & $0.8 \mathrm{ml}$ per min \\
\hline Wavelength & $260 \mathrm{~nm}$ \\
\hline Injection volume & $20 \mu \mathrm{l}$ \\
\hline Run time & $10 \mathrm{~min}$ \\
\hline
\end{tabular}

Table 2: Linearity results: (for Metoprolol)

\begin{tabular}{|c|c|}
\hline Concentration of MET in ppm & Peak area \\
\hline 0 & 0 \\
\hline 25 & 284011 \\
\hline 50 & 565789 \\
\hline 75 & 803165 \\
\hline 100 & 1078798 \\
\hline 125 & 1308468 \\
\hline 150 & 1592569 \\
\hline
\end{tabular}

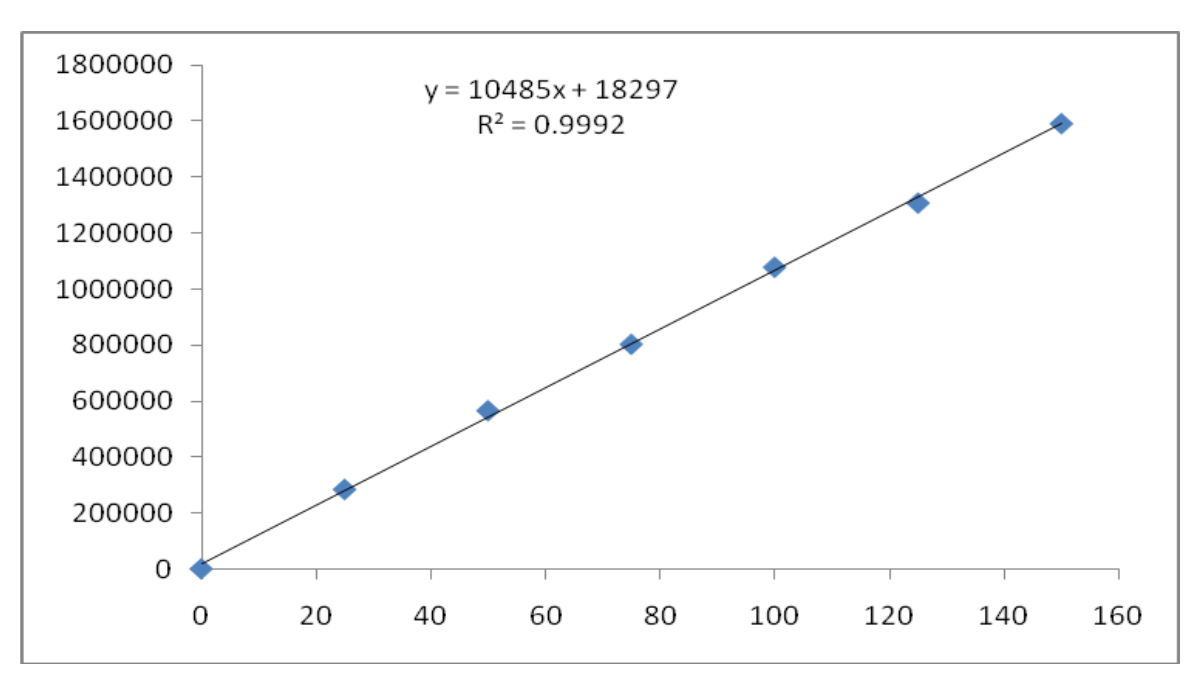

Figure 4: Calibration curve of Metoprolol

Table 3: Linearity results: (for Ivabradine)

\begin{tabular}{|c|c|}
\hline Concentration of IVR in ppm & Peak area of Olmesartan \\
\hline 0 & 0 \\
\hline 5 & 42951 \\
\hline 10 & 86790 \\
\hline 15 & 129434 \\
\hline 20 & 172080 \\
\hline 25 & 218488 \\
\hline 30 & 255893 \\
\hline
\end{tabular}




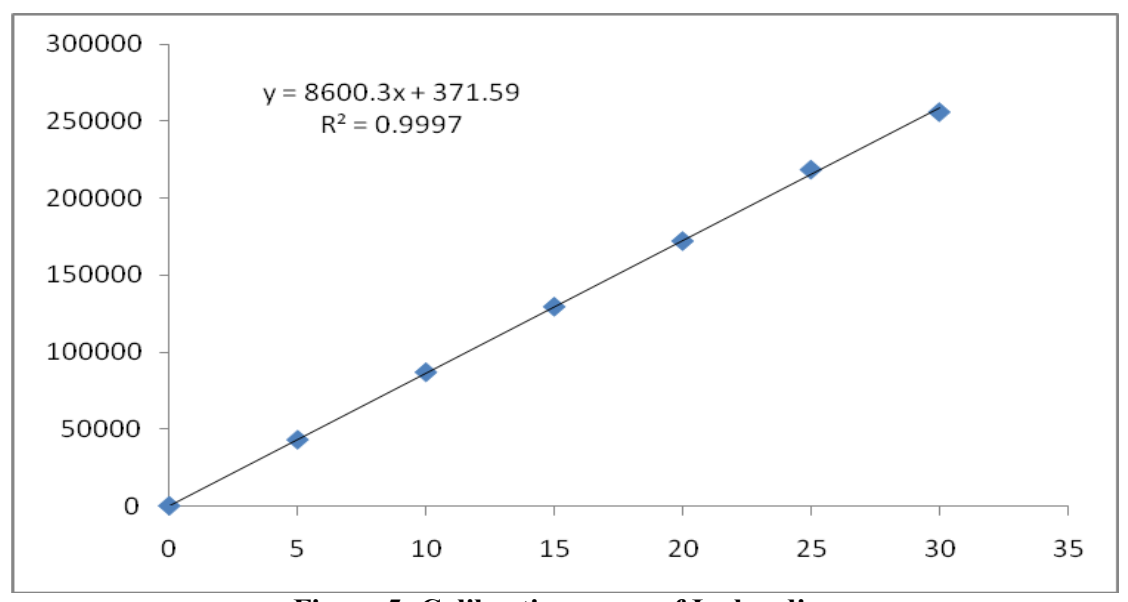

Figure 5: Calibration curve of Ivabradine

Table 4: Results of Intermediate precession for Metoprolol

\begin{tabular}{|c|c|c|c|c|c|}
\hline S. No. & Peak name & Rt & Area $\left(\mu V^{*}\right.$ sec $)$ & USP Plate Count & USP Tailing \\
\hline 1 & Metoprolol & 2.23 & 990531 & 7818 & 1.23 \\
\hline 2 & Metoprolol & 2.23 & 995548 & 7768 & 1.25 \\
\hline 3 & Metoprolol & 2.23 & 989696 & 7490 & 1.25 \\
\hline 4 & Metoprolol & 2.24 & 992954 & 7757 & 1.23 \\
\hline 5 & Metoprolol & 2.23 & 990770 & 7758 & 1.25 \\
\hline 6 & Metoprolol & & 994301 & 7470 & 1.23 \\
\hline & Mean & & 992300 & & \\
\hline & Std. Dev & & 2333.8 & & \\
\hline & \% RSD & & 0.2 & & \\
\hline
\end{tabular}

Table 5: Results of Intermediate precession for Ivabradine

\begin{tabular}{|c|c|c|c|c|c|}
\hline S. No. & Peak Name & Rt & Area $(\mu \mathrm{V})$ & USP Tailing & USP Plate Count \\
\hline 1 & Ivabradine & 2.65 & 158333 & 1.17 & 8425 \\
\hline 2 & Ivabradine & 2.66 & 158364 & 1.16 & 8940 \\
\hline 3 & Ivabradine & 2.65 & 159749 & 1.16 & 9081 \\
\hline 4 & Ivabradine & 2.66 & 160368 & 1.15 & 8732 \\
\hline 5 & Ivabradine & 2.66 & 159388 & 1.14 & 8854 \\
\hline 6 & Ivabradine & 2.65 & 157989 & 1.16 & 8770 \\
\hline & Mean & & 159032 & & \\
\hline & Std. Dev. & & 943.2 & & \\
\hline & \% RSD & & 0.6 & & \\
\hline
\end{tabular}

Table 6: System precision table of Ivabradine and Metoprolol

\begin{tabular}{|c|c|c|}
\hline S. No & Area of Ivabradine & Area of Metoprolol \\
\hline 1. & 172986 & 1065156 \\
\hline 2. & 172721 & 1059477 \\
\hline 3. & 172916 & 1063748 \\
\hline 4. & 173381 & 1060344 \\
\hline 5. & 173028 & 1060037 \\
\hline 6. & 174028 & 1052631 \\
\hline Mean & 173177 & 1060232 \\
\hline S.D & 469.2 & 4359.0 \\
\hline \%RSD & 0.3 & 0.4 \\
\hline
\end{tabular}


Table 7: Accuracy studies for Ivabradine

\begin{tabular}{|c|c|c|c|c|c|}
\hline$\%$ Concentration & Area & $\begin{array}{c}\text { Amount added } \\
(\mu \mathrm{g})\end{array}$ & $\begin{array}{c}\text { Amount } \\
\text { Found }(\mu \mathrm{g})\end{array}$ & $\%$ recovery & $\begin{array}{c}\text { Mean } \\
\text { Recovery }\end{array}$ \\
\hline \multirow{3}{*}{$50 \%$} & 262339 & 10 & 10.07 & 100.73 & \multirow{9}{*}{$99.86 \%$} \\
\hline & 261113 & 10 & 9.93 & 99.30 & \\
\hline & 260937 & 10 & 9.91 & 99.10 & \\
\hline \multirow{3}{*}{$100 \%$} & 348205 & 20 & 20.06 & 100.28 & \\
\hline & 346672 & 20 & 19.88 & 99.39 & \\
\hline & 346504 & 20 & 19.86 & 99.30 & \\
\hline \multirow{3}{*}{$150 \%$} & 435032 & 30 & 30.15 & 100.51 & \\
\hline & 432723 & 30 & 29.88 & 99.62 & \\
\hline & 435074 & 30 & 30.16 & 100.53 & \\
\hline
\end{tabular}

Table 8: Accuracy results for Metoprolol

\begin{tabular}{|c|c|c|c|c|}
\hline $\begin{array}{c}\% \text { Concentration } \\
\text { (at specification Level) }\end{array}$ & Area & $\begin{array}{c}\text { Amount added } \\
\text { (mg) }\end{array}$ & $\begin{array}{c}\text { Amount } \\
\text { Found (mg) }\end{array}$ & $\%$ recovery \\
\hline \multirow{3}{*}{$50 \%$} & 1595668 & 50 & 50.44 & 100.88 \\
\hline & 1590916 & 50 & 49.99 & 99.98 \\
\hline & 1591791 & 50 & 50.07 & 100.14 \\
\hline \multirow{3}{*}{$100 \%$} & 2101313 & 100 & 98.67 & 98.67 \\
\hline & 2109097 & 100 & 99.41 & 99.41 \\
\hline & 2109840 & 100 & 99.48 & 99.48 \\
\hline \multirow{3}{*}{$150 \%$} & 2616195 & 150 & 147.77 & 98.52 \\
\hline & 2638896 & 150 & 149.94 & 99.96 \\
\hline & 2630008 & 150 & 149.09 & 98.52 \\
\hline & & & & 99.96 \\
\hline & \multicolumn{3}{|c|}{ Table 9: LOD and LOQ } & 99.39 \\
\hline & \multicolumn{2}{|c|}{ Molecule } & LOD & LOQ \\
\hline & \multicolumn{2}{|c|}{ Ivabradine } & 1.25 & 3.80 \\
\hline & \multicolumn{2}{|c|}{ Metoprolol } & 19 & 0.56 \\
\hline
\end{tabular}

Table 10: Robustness data for Metoprolol

\begin{tabular}{|c|c|c|}
\hline S. No. & Condition & \%RSD of Metoprolol \\
\hline 1 & Flow rate (-) $0.9 \mathrm{ml} / \mathrm{min}$ & 0.9 \\
\hline 2 & Flow rate (+) $1.1 \mathrm{ml} / \mathrm{min}$ & 1.0 \\
\hline 3 & Mobile phase (-) 55B:45A & 1.1 \\
\hline 4 & Mobile phase $(+) 45 \mathrm{~B}: 55 \mathrm{~A}$ & $\mathbf{1 . 2}$ \\
\hline 5 & Temperature $(-) 25^{\circ} \mathrm{C}$ & 0.8 \\
\hline 6 & Temperature $(+) 35^{\circ} \mathrm{C}$ & 0.7 \\
\hline
\end{tabular}

Table 11: Results of robustness for and Ivabradine

\begin{tabular}{|c|c|c|}
\hline S. No. & Condition & \% RSD of Ivabradine \\
\hline 1 & Flow rate (-) 0.9ml/min & 0.8 \\
\hline 2 & Flow rate (+) $1.1 \mathrm{ml} / \mathrm{min}$ & $\mathbf{0 . 7}$ \\
\hline 3 & Mobile phase (-) 55B:45A & 0.7 \\
\hline 4 & Mobile phase (+) 45B:55A & 0.8 \\
\hline 5 & Temperature (-) $25^{\circ} \mathrm{C}$ & $\mathbf{1 . 0}$ \\
\hline 6 & Temperature (+) $35^{\circ} \mathrm{C}$ & \\
\hline
\end{tabular}

$99.96 \%$

Mean Recovery 


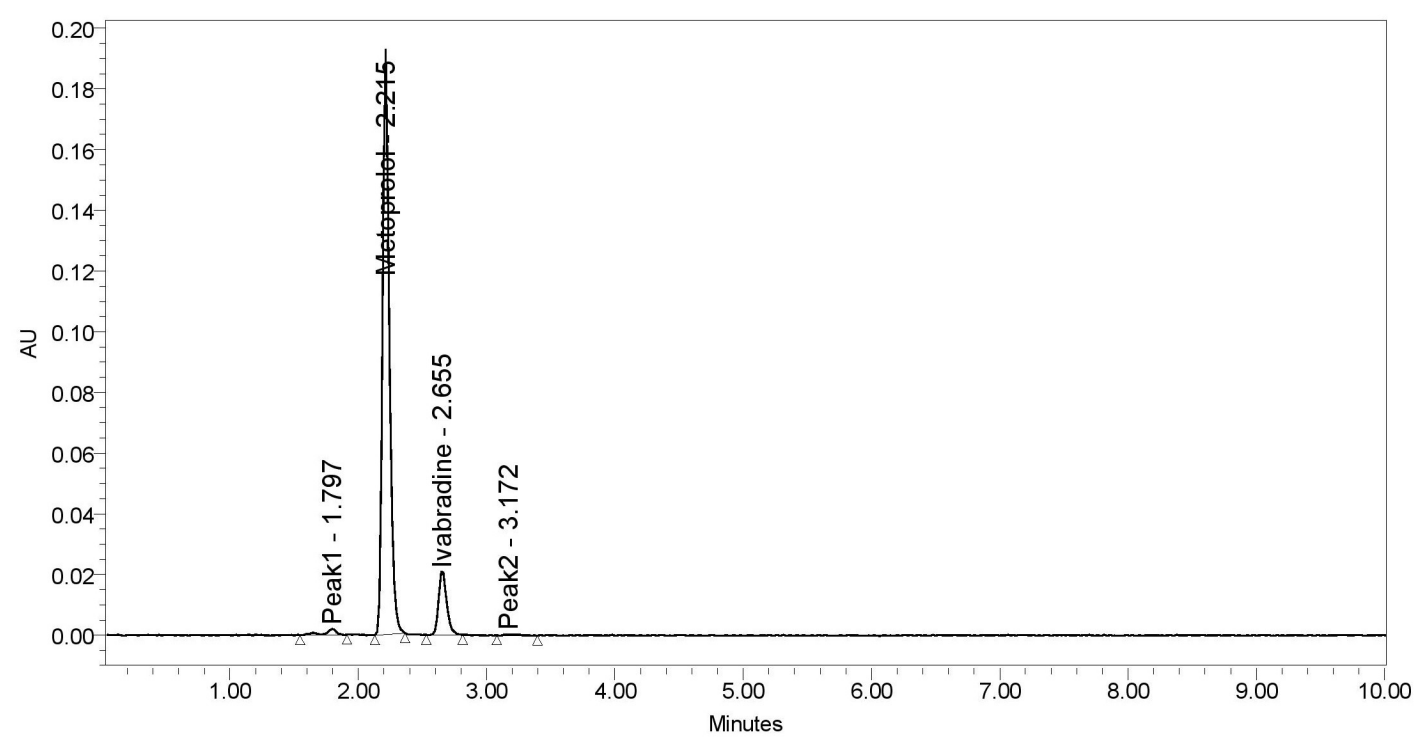

Figure 6: Chromatogram showing degradation for Metoprolol and Ivabradine in $0.1 \mathrm{~N} \mathrm{HCl}$

\begin{tabular}{|c|c|c|c|c|c|}
\hline S. No. & Peak Name & $\mathbf{R}_{\mathbf{t}}$ & Area & $\begin{array}{c}\text { USP } \\
\text { Tailing }\end{array}$ & $\begin{array}{c}\text { USP plate } \\
\text { count }\end{array}$ \\
\hline 1 & Peak 1 & 1.79 & 11756 & $\mathbf{0 . 6}$ & 5165 \\
\hline 2 & Metoprolol & 2.21 & 1024382 & 1.2 & 8193 \\
\hline 3 & Ivabradine & 2.655 & 162874 & 1.2 & 8646 \\
\hline 4 & Peak 2 & 3.17 & 2937 & 2.3 & 14948 \\
\hline
\end{tabular}

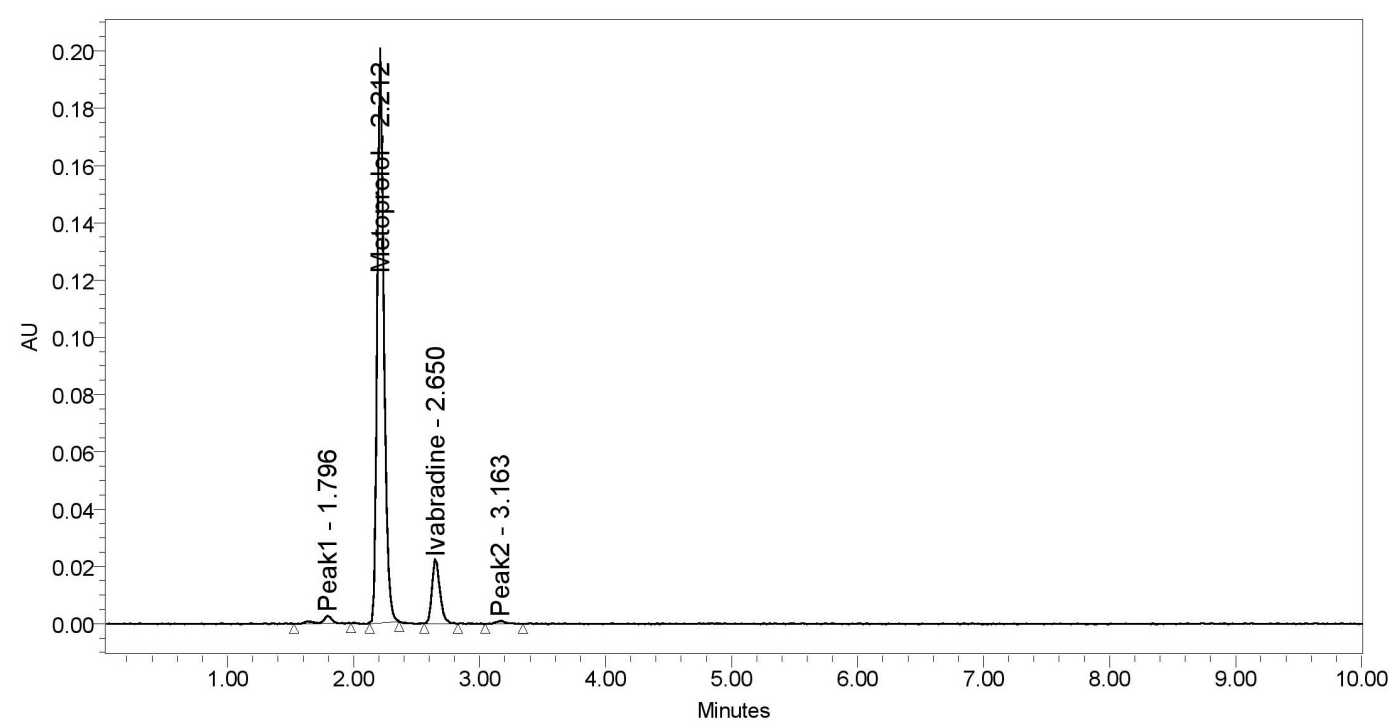

Figure 7: Chromatogram showing degradation related impurity in $0.1 \mathrm{~N} \mathrm{NaOH}$

\begin{tabular}{|c|c|c|c|c|c|}
\hline S. No. & Peak Name & $\mathbf{R}_{\mathbf{t}}$ & Area & $\begin{array}{c}\text { USP } \\
\text { Tailing }\end{array}$ & $\begin{array}{c}\text { USP plate } \\
\text { count }\end{array}$ \\
\hline 1 & Peak 1 & 1.79 & 14618 & $\mathbf{0 . 7}$ & 4758 \\
\hline 2 & Metoprolol & 2.21 & 1029339 & 1.2 & $\mathbf{8 0 5 8}$ \\
\hline 3 & Ivabradine & 2.65 & 163416 & 1.2 & 8387 \\
\hline 4 & Peak 2 & 3.16 & 4987 & 1.1 & 6992 \\
\hline
\end{tabular}




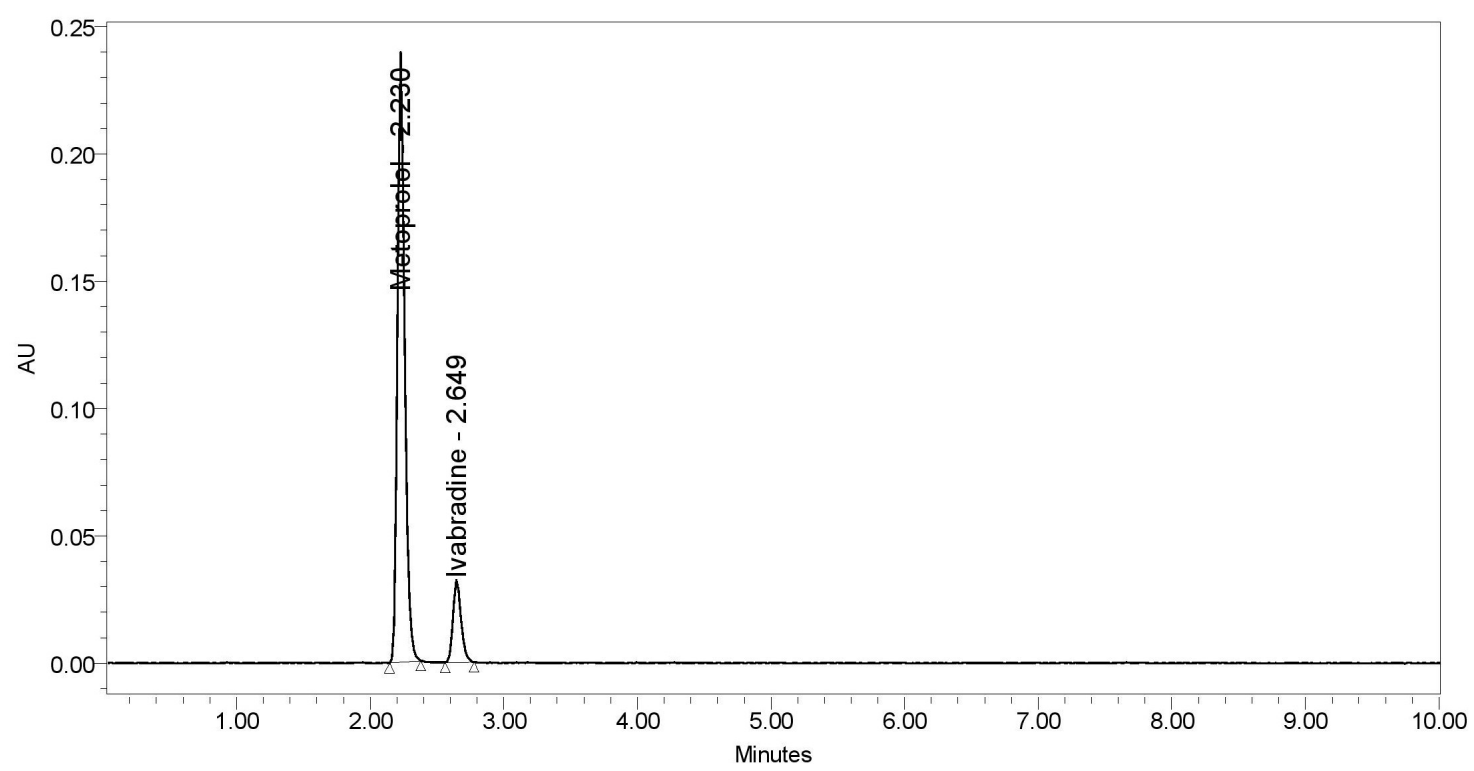

Figure 8: Chromatogram showing thermal degradation studies

\begin{tabular}{|c|c|c|c|c|c|}
\hline S. No. & Peak Name & $\mathbf{R}_{\mathbf{t}}$ & Area & $\begin{array}{c}\text { USP } \\
\text { Tailing }\end{array}$ & $\begin{array}{c}\text { USP plate } \\
\text { count }\end{array}$ \\
\hline 1 & Metoprolol & 2.23 & 1039367 & 1.2 & 7991 \\
\hline 2 & Ivabradine & 2.64 & 168933 & 1.2 & 9083 \\
\hline
\end{tabular}

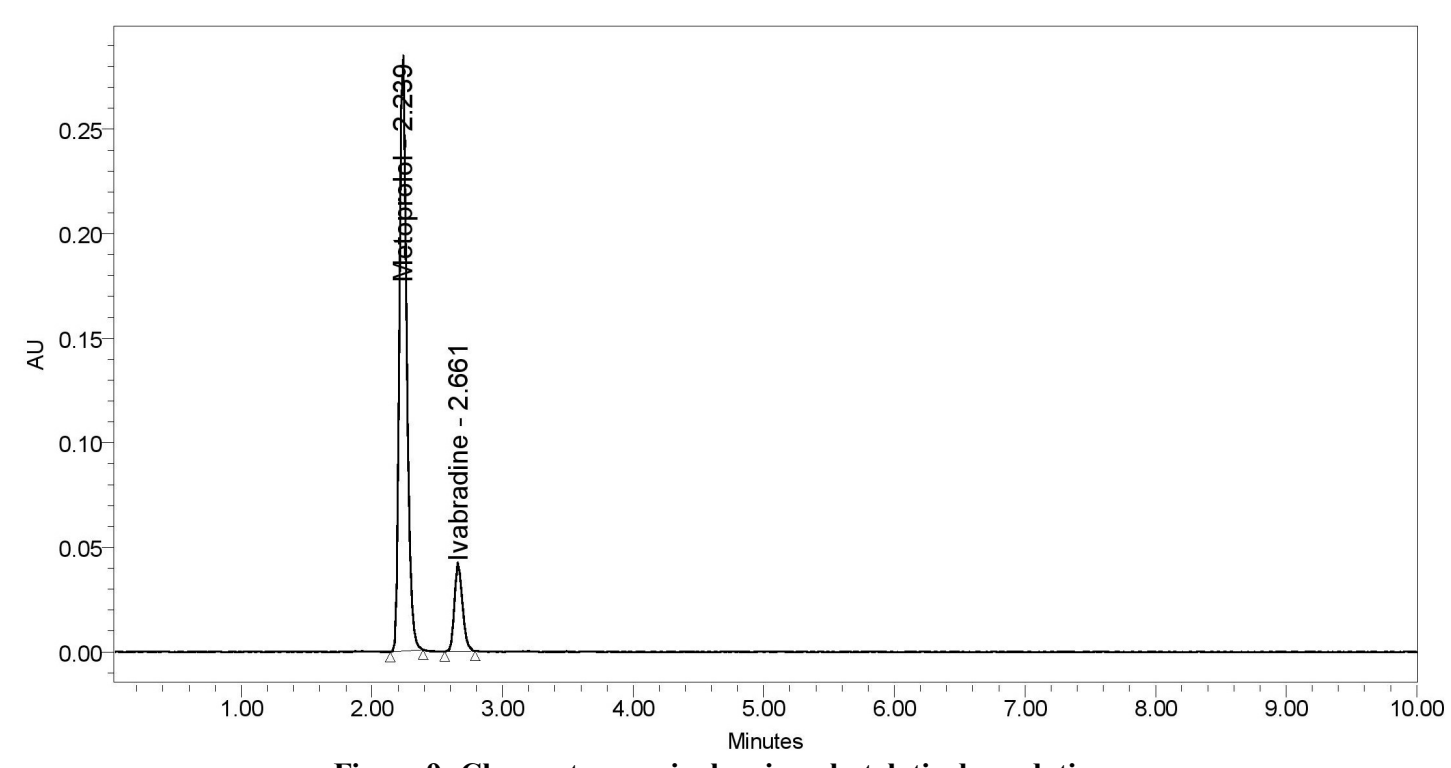

Figure 9: Chromatogram is showing photolytic degradation

\begin{tabular}{|c|c|c|c|c|c|}
\hline S. No. & Peak Name & $\mathbf{R}_{\mathbf{t}}$ & Area & $\begin{array}{c}\text { USP } \\
\text { Tailing }\end{array}$ & $\begin{array}{c}\text { USP plate } \\
\text { count }\end{array}$ \\
\hline 1 & Metoprolol & $\mathbf{2 . 2 3}$ & $\mathbf{1 0 4 8 2 5 8}$ & 1.2 & 7661 \\
\hline 2 & Ivabradine & $\mathbf{2 . 6 6}$ & $\mathbf{1 7 0 7 4 0}$ & 1.2 & 9287 \\
\hline
\end{tabular}




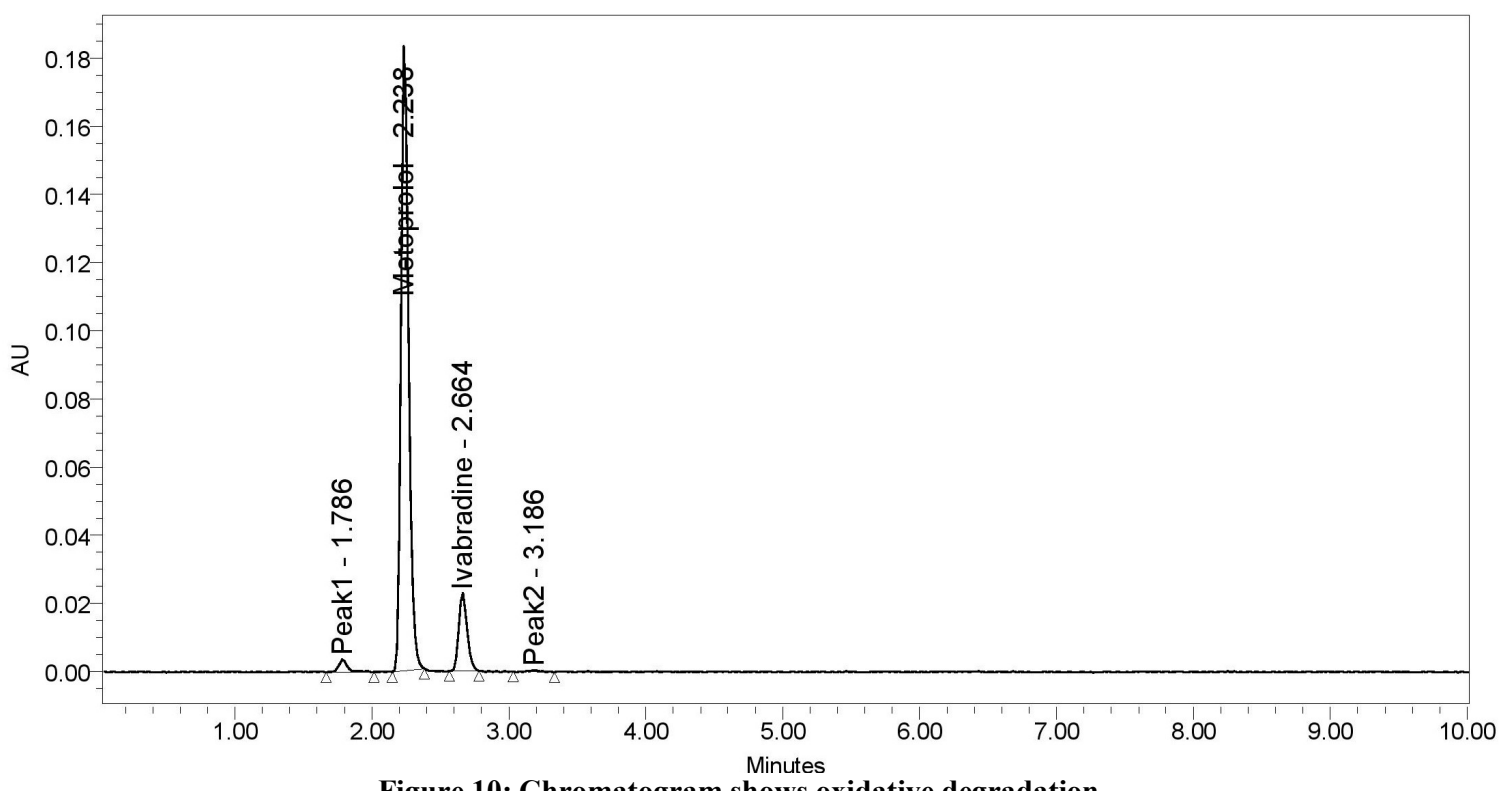

Figure 10: Chromatogram shows oxidative degradation

\begin{tabular}{|c|c|c|c|c|c|}
\hline S. No. & Peak Name & $\mathbf{R}_{\mathbf{t}}$ & Area & $\begin{array}{c}\text { USP } \\
\text { Tailing }\end{array}$ & $\begin{array}{c}\text { USP plate } \\
\text { count }\end{array}$ \\
\hline 1 & Peak 1 & 1.78 & 14618 & 1.3 & 4195 \\
\hline 2 & Metoprolol & 2.23 & 1029339 & 1.2 & 7632 \\
\hline 3 & Ivabradine & 2.66 & 162691 & 1.2 & 9155 \\
\hline 4 & Peak 2 & 3.16 & 4987 & 1.6 & 2181 \\
\hline
\end{tabular}

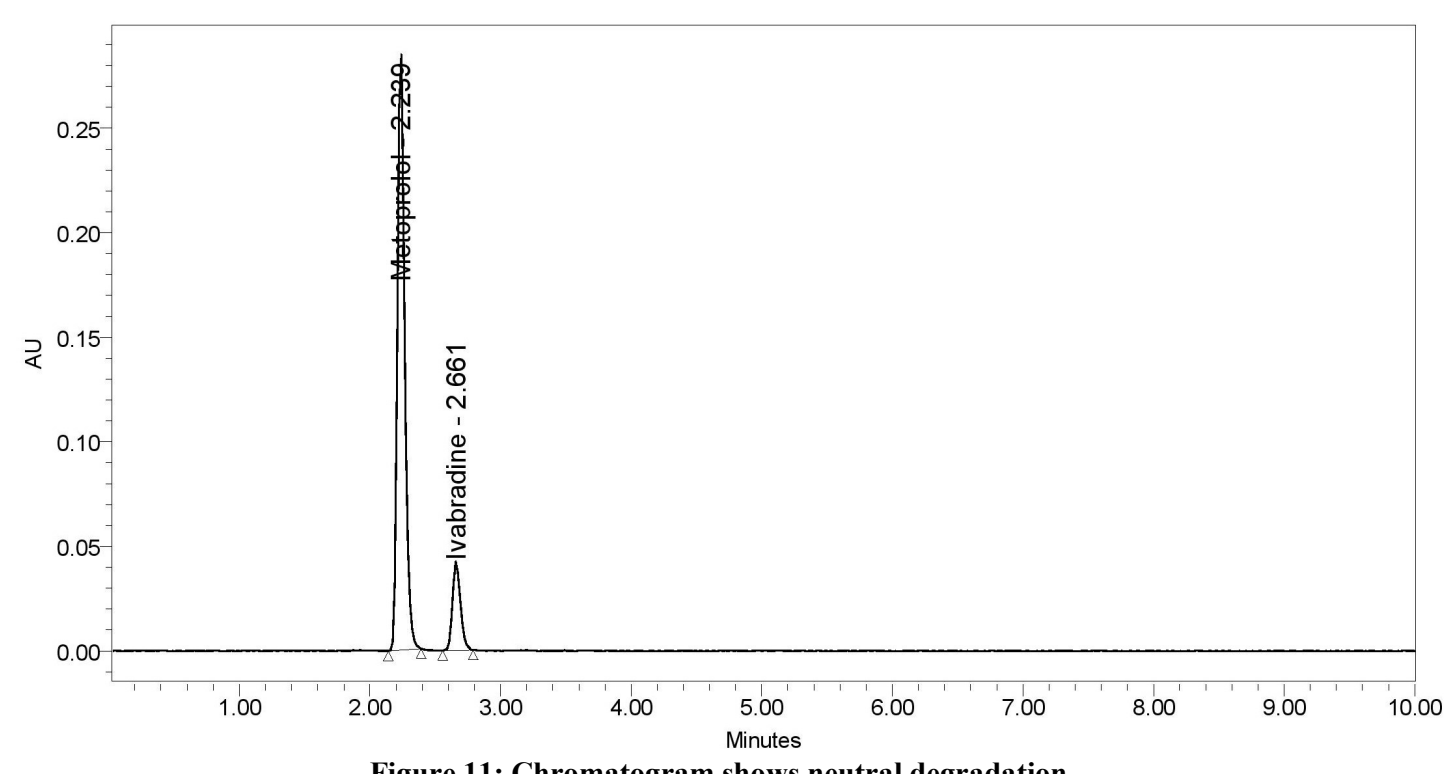

Figure 11: Chromatogram shows neutral degradation

\begin{tabular}{|c|c|c|c|c|c|}
\hline S. No. & Peak Name & $\mathbf{R}_{\mathrm{t}}$ & Area & $\begin{array}{c}\text { USP } \\
\text { Tailing }\end{array}$ & $\begin{array}{c}\text { USP plate } \\
\text { count }\end{array}$ \\
\hline 1 & Metoprolol & 2.23 & 1060581 & 1.2 & 7651 \\
\hline 2 & Ivabradine & 2.66 & 172556 & 1.2 & 9187 \\
\hline
\end{tabular}


Table 12: Results of forced degradation studies of Ivabradine and Metoprolol

\begin{tabular}{|c|c|c|c|c|c|c|}
\hline \multirow[t]{2}{*}{ Type of degradation } & \multicolumn{3}{|c|}{ Ivabradine } & \multicolumn{3}{|c|}{ Metoprolol } \\
\hline & Area & \%recovered & $\%$ degraded & Area & \%recovered & $\%$ degraded \\
\hline Acid (0.1 M HCl) & 162874 & 93.86 & 6.14 & 1024382 & 96.23 & 3.77 \\
\hline Base (0.1 M NaOH) & 163416 & 94.18 & 5.82 & 1029339 & 96.70 & 3.30 \\
\hline Peroxide $\left(3 \% \mathrm{H}_{2} \mathrm{O}_{2}\right)$ & 162691 & 93.16 & 6.24 & 1033319 & 97.07 & 2.93 \\
\hline Thermal $\left(80^{0} \mathrm{C}\right)$ & 168933 & 9735 & 2.65 & 1039367 & 97.64 & 2.36 \\
\hline Uv 254nm & 170740 & 98.40 & 1.60 & 1048258 & 98.48 & 1.52 \\
\hline Water & 172556 & 99.44 & 0.56 & 1060581 & 99.63 & 0.37 \\
\hline
\end{tabular}

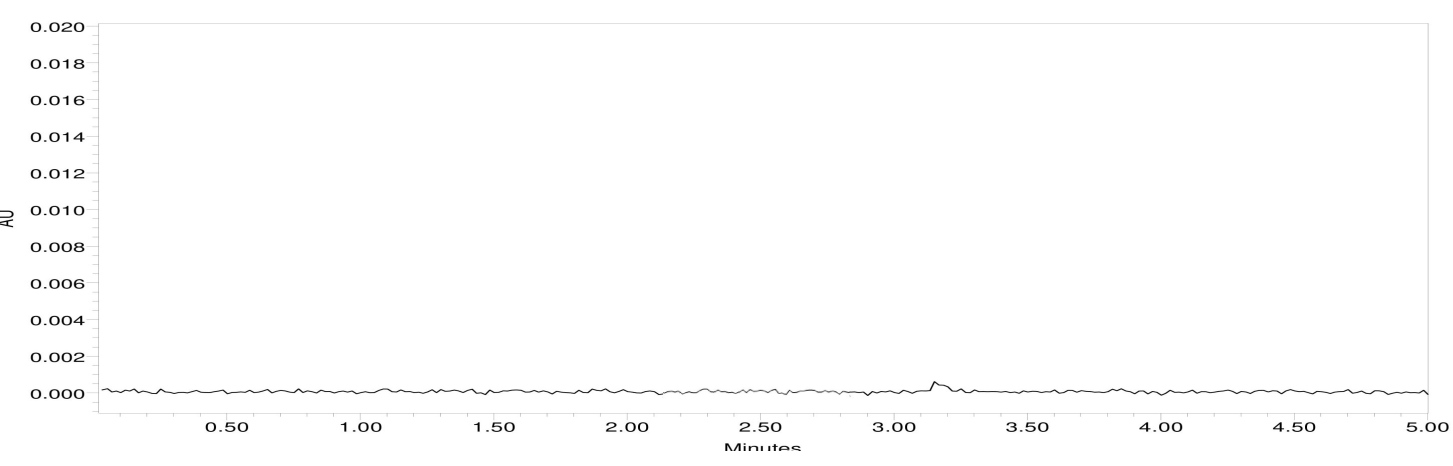

Figure 12: Chromatogram of blank plasma

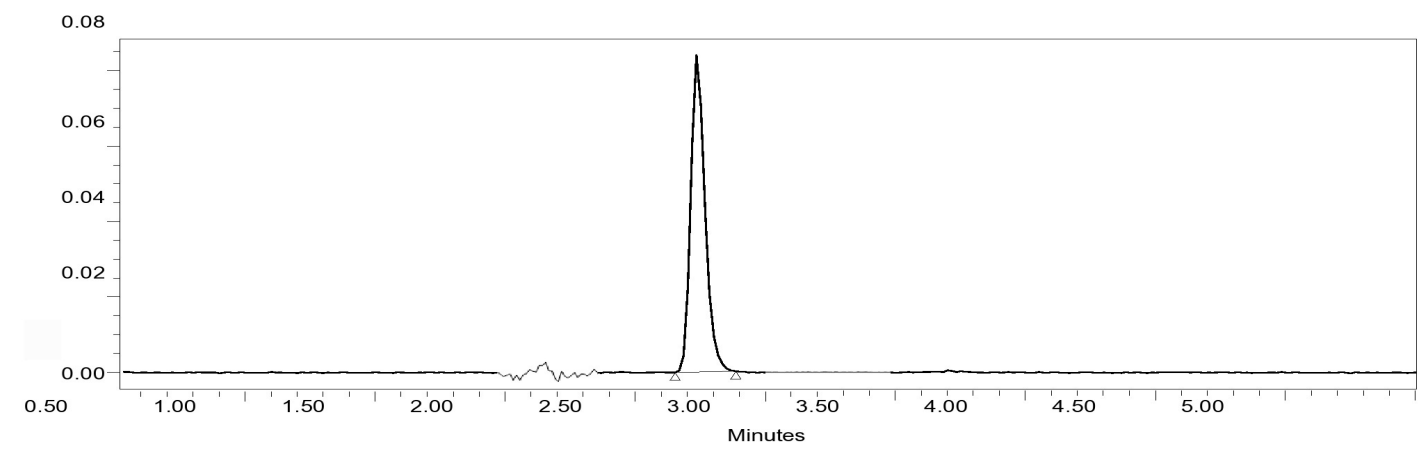

Figure 13: Chromatogram shows standard drug Metoprolol spiked with plasma

\begin{tabular}{|c|c|c|c|c|c|}
\hline S. No. & Peak Name & $\mathbf{R}_{\mathbf{t}}$ & Area & USP Tailing & USP plate count \\
\hline 1 & Metoprolol & $\mathbf{2 . 2 4}$ & $\mathbf{2 8 1 4 3 6}$ & $\mathbf{1 . 2}$ & $\mathbf{7 8 2 2}$ \\
\hline
\end{tabular}

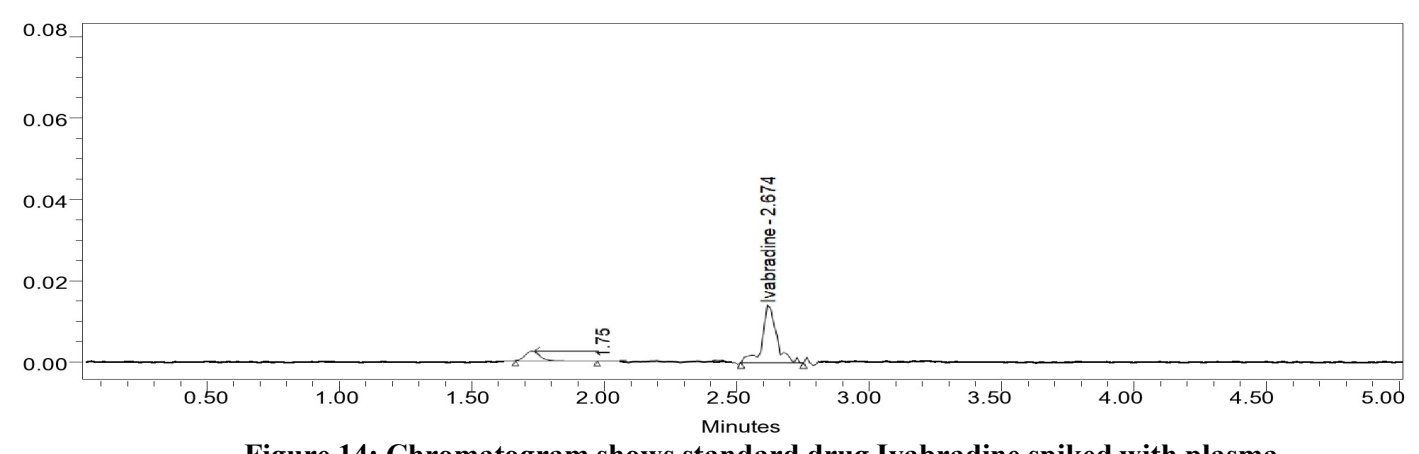

Figure 14: Chromatogram shows standard drug Ivabradine spiked with plasma 


\begin{tabular}{|c|c|c|c|c|c|}
\hline S. No. & Peak Name & $\mathbf{R}_{\mathbf{t}}$ & Area & $\begin{array}{c}\text { USP } \\
\text { Tailing }\end{array}$ & $\begin{array}{c}\text { USP plate } \\
\text { count }\end{array}$ \\
\hline 1 & Peak 1 & 1.75 & 11722 & 0.6 & 4985 \\
\hline 2 & Ivabradine & 2.67 & 42925 & 1.12 & 9245 \\
\hline
\end{tabular}

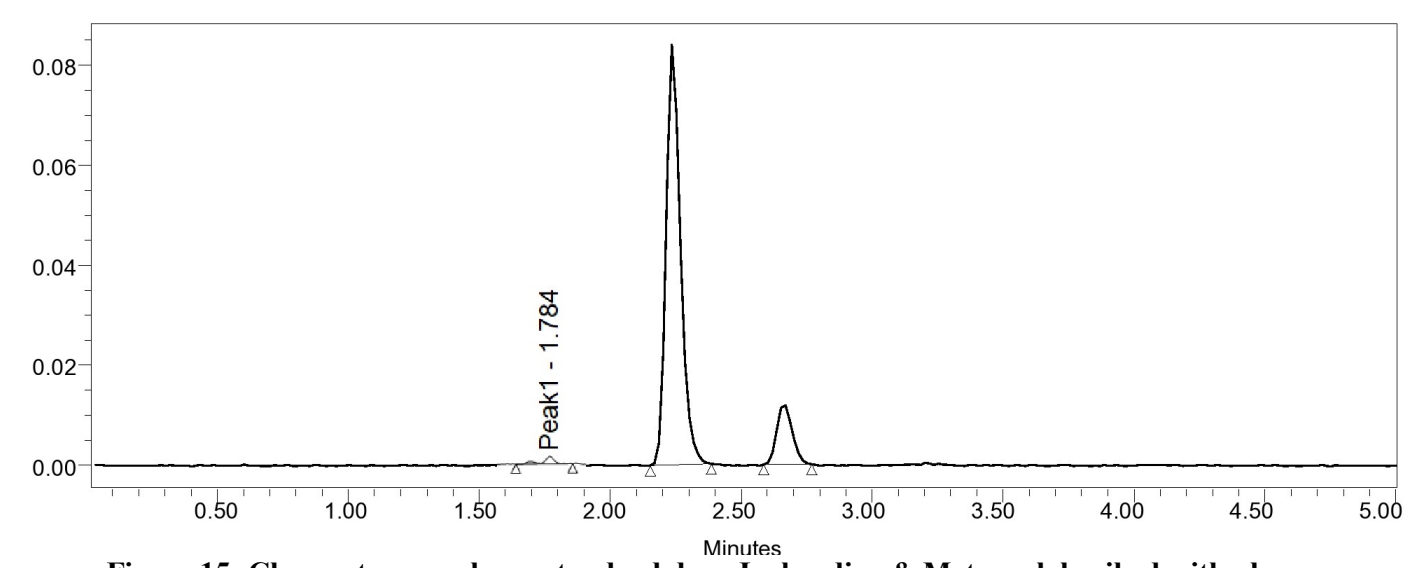

Figure 15: Chromatogram shows standard drug Ivabradine \& Metoprolol spiked with plasma

\begin{tabular}{|c|c|c|c|c|c|}
\hline S. No. & Peak Name & $\mathbf{R}_{\mathbf{t}}$ & Area & $\begin{array}{c}\text { USP } \\
\text { Tailing }\end{array}$ & $\begin{array}{c}\text { USP plate } \\
\text { count }\end{array}$ \\
\hline 1 & Peak 1 & $\mathbf{1 . 7 8 4}$ & $\mathbf{1 1 7 5 6}$ & $\mathbf{0 . 6}$ & 4985 \\
\hline 2 & Metoprolol & 2.24 & $\mathbf{2 8 1 4 8 7}$ & 1.18 & $\mathbf{8 1 4 2}$ \\
\hline 3 & Ivabradine & 2.67 & 43006 & 1.10 & $\mathbf{8 9 3 6}$ \\
\hline
\end{tabular}

\section{CONCLUSION}

High performance liquid chromatography is at present one of the most sophisticated tool of the analysis. The estimation of Ivabradine and Metoprolol was done by RP-HPLC. The proposed method was found to be simple, precise, accurate and rapid for determination of Ivabradine and Metoprolol in pure and dosage form. The mobile phase is simple to prepare and economical. The sample recoveries in all formulations were in good agreement within the limit. Hence, this method can be easily and conveniently adopted for routine analysis of Ivabradine and Metoprolol in pure form, dosage form and in plasma

\section{ACKNOWLEDGEMENTS}

I, Dhiraj Kumar, thankful to Dr. P. Suresh, Associate Director, School of Pharmacy, GNITC Campus, Ibrahimpattnam, Hyderabad, for providing necessary facilities to carry out the research work.

\section{REFERENCE}

[1] https://go.drugbank.com/drugs/DB00 264

[2] https://en.wikipedia.org/wiki/Ivabradi ne 
[3] https://go.drugbank.com/drugs/DB00 264

[4] https://www.webmd.com/drugs/2/dru g-5891/amlodipine-oral/details

[5] https://www.webmd.com/drugs/2/dru g-63172/olmesartan-oral/details

[6] Draft ICH Guidelines on Validation of Analytical Procedures Definitions and terminology. Federal Register, 1995, Volume 60. IFPMA, Switzerland, PP 1126.

[7] Sanapathi Rajakumari, Galla Rajitha and Adepu Geetha Susmita, Development and validation of stability indicating RP-HPLC method for simultaneous estimation of ivabradine and metoprolol in tablet dosage form, International journal of pharmaceutical sciences and research, 11(6), 2020, 2786-2792.

[8] Anjali P., Y. Padmavathi, K. Ravi, N. Raghavendra, Quantitative bioanalytical and analytical methods for estimation of ivabradine hydrochloride in pure and pharmaceutical dosage form, Asian Journal of research in chemistry, 9(1), 2021,1-10.

[9] Nadia M. Mostafa, Yasmin M. Fayez , Joliana F. Farid, Validated stability indicating chromatographic methods for determination of Ivabradine hydrochloride in the presence of its acidic degradation product, Analytical chemistry letters, Vol.7 (2), 2016, 280-294

[10] P. R. Boratwar, P. P. Jumade, R. D. Bawankar, D. S. Wanjari, D. R. Mundhada, Development and validation for simultaneous estimation of drug in combination from pharmaceutical formulation by RP-HPLC method, International journal of pharmtech research, 14(,1), 2021, 51-56.

[11] Sangameshwar B. Kanthale1, Sanjay S. Thonte2, Debarshi Kar Mahapatra, Stability indicating RPHPLC method for the simultaneous estimation of ivabradine and metoprolol in bulk and tablet formulation, 9(4), 2019, 2841-2847.

[12] Suresh Gandi, A. Manikandan, S. Venkat Rao, Novel stability indicating rp-uplc method for simultaneous determination of ivabradine and metoprolol drug materials in bulk and their pharmaceutical dosage forms, Research journal of pharmacy and technology, 13(1), 2020 84-89.

[13] Deepak Kumar Jain, development and validation of RP-HPLC method 
for estimation of amlodipine besylate, olmesartan medoxomil and hydrochlorthiazide in tablet dosage form, International Journal of Research in Ayurveda and Pharmacy, 5(4), 2014, 523-530 .

[14] Bidkar J. S., Vare S.R., Dama G. Y., Shelke M. M. and Dhokare A. Developement and validation of stability indicating RP-HPLC method for the estimation of metoprolol and ivabradine in solid dosage form, World journal of pharmaceutical research, 8(7), 2019, 1712-1768.

[15] Selva Kumar P, Pandiyan K, Rajagopal K, Development and validation of stability indicating rapid hplc method for estimation of ivabradine hydrochloride in solid oral dosage form, International Journal of Pharmacy and Pharmaceutical Sciences, 5(1), 2014, 329-335.

[16] Selva Kumar P, Pandiyan K, Rajagopal K, Development and validation of stability indicating rapid hplc method for estimation of ivabradine hydrochloride in solid oral dosage form, International Journal of pharmacy and pharmaceutical sciences, 6(14), 2014, 377-382

[17] Napa Raj, $\quad$ Sockalingam Anbazhagan, Kunapareddy Anudeep Babu, Sunkara Narendra Babu, Chusena Narasimharaju Bhimanadhuni, International Current Pharmaceutical Journal, 1(11), 2012, 336-341. 